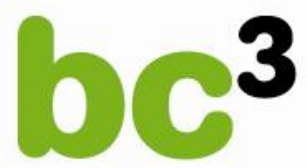

BASQUE CENTRE

FOR CLIMATE CHANGE

Klima Aldaketa Ikergai

\title{
The Demand for Environmental Quality in \\ Driving Transitions to Low Polluting Energy Sources
}

\author{
Roger Fouquet
}

November 2011

BC3 WORKING PAPER SERIES 
The Basque Centre for Climate Change (BC3) is a Research Centre based in the Basque Country, which aims at contributing to long-term research on the causes and consequences of Climate Change in order to foster the creation of knowledge in this multidisciplinary science.

The BC3 promotes a highly-qualified team of researchers with the primary objective of achieving excellence in research, training and dissemination. The Scientific Plan of BC3 is led by the Scientific Director, Prof. Anil Markandya.

The core research avenues are:

- Adaptation to and the impacts of climate change

- Measures to mitigate the amount of climate change experienced

- International Dimensions of Climate Policy

- Developing and supporting research that informs climate policy in the Basque Country

See www.bc3research.org for further details.

The BC3 Working Paper Series is available on the internet at http://www.bc3research.org/lits_publications.html

Enquiries (Regarding the BC3 Working Paper Series):

Roger Fouquet

Email: roger.fouquet@bc3research.org

www.bc3research.org

The opinions expressed in this working paper do not necessarily reflect the position of Basque Centre for Climate Change (BC3) as a whole.

Note: If printed, please remember to print on both sides. Also, perhaps try two pages on one side. 


\title{
The Demand for Environmental Quality in Driving Transitions to Low Polluting Energy Sources
}

\author{
Roger Fouquet ${ }^{1}$
}

The purpose of this paper is to understand the long run demand for energy-related environmental quality, its influence on legislation and on transitions to low polluting energy sources. It starts by presenting a simple framework of the relationship between the demand for and supply of environmental quality, environmental legislation and energy. This forms the structure for presenting a series of episodes in British history where a demand for improvements in energy-related environmental quality existed. This analysis proposes that markets can drive transitions to low polluting energy sources, in specific economic conditions. However, most probably, governments will need to push them, and this cannot be expected without strong and sustained demand for environmental improvements. Yet, while demand is a prerequisite, it is not enough. It must also be spearheaded by strong, creative and sustained pressure groups (i.e., powerful lobbying and the weakening of the counter-lobby) to introduce legislation, to enforce it and to avoid it being over-turned by future governments.

Keywords: Energy Transitions, Historical, Environmental Quality, Air Pollution.

JEL Classification: Q41, Q53, Q54, N73, N74

Cite as: Fouquet, R. (2011) The Demand for Environmental Quality in Driving Transitions to Low Polluting Energy Sources. BC3 Working Paper Series 2011-11. Basque Centre for Climate Change (BC3). Bilbao, Spain.

\footnotetext{
${ }^{1}$ Basque Centre for Climate Change (BC3). Alameda Urquijo, 4 - 4॰, 48008 Bilbao, Spain; and IKERBASQUE, Basque Foundation for Science. Alameda Urquijo 36-5, 48011 Bilbao, Spain. Corresponding author E-mail: roger.fouquet@bc3research.org.
} 


\section{Introduction}

A transition to a low carbon economy is seen as a possible solution to meeting the demand for climate stability (Grubb et al. 2008, Foxon et al. 2008). Given society and policy-makers' interest in transitions from the existing fossil fuel-dominated energy system, it might be valuable to identify how past energy transitions have evolved. These may offer insights that are relevant for how to or how not to aid a desired transition.

While a number of studies have investigated historical energy transitions (Schurr and Netschert 1960, Cipolla 1962, Humphrey and Stanislaw 1979, Fouquet and Pearson 1998, Grübler 2004, Gales et al. 2007, Bartoletto and Rubio 2008, Kunnas and Myllyntaus 2009), offering a rich understanding of their nature and implications, fewer have explored the drivers of these transitions. Smil (2010) emphasized the key role new technologies played in generating past energy transitions. Grübler et al (1999) identified that technological innovations depend on achieving economies of scale in production. Geels (2002) showed how the co-evolution of technologies, industries and institutions enabled new energy sources to emerge. Madureira (2008) highlighted the role played by resource endowments and government objectives. Allen (2012) stressed the importance of prices in driving energy transitions.

The conclusion from a review of fourteen past experiences was that any future transition seems likely to occur only if the new combination of energy sources and technologies provides cheaper services (Fouquet 2010). In addition, a transition to a low carbon economy might require a qualitative change in the energy sources. In a number of past cases, the substitution enabled qualitative changes in the nature of the service provided, and niches of consumers were willing to pay more for the associated additional value. However, the additional value was associated with private benefits.

Most of the benefits of a consumer buying low carbon energy sources will be passed on to society as a whole, rather than generating large private gains. So, voluntary efforts to reduce emissions by using low polluting (i.e. higher value) but more expensive energy sources are likely to be hampered by the tendency for many consumers to free-ride.

Nevertheless, society and individuals appear to value reductions in carbon dioxide emissions and a transition to low carbon energy sources (Brouwer et al 2008, Lee and Cameron 2008, Mackerron et al 2009, Löschel 2010, Diedrich and Goeschl 2011). Given this demand for climate stability and a social benefit from a transition to low carbon energy sources, yet a tendency to free-ride, it is important to improve our understanding of how this demand might be met and such a transition might be achieved.

The purpose of this paper is to focus-in on past experiences to identify the factors that enabled the demand for environmental quality to become environmental legislation, and the factors that led a 
transition to a low polluting energy source to become a key part of the legislation to meet this demand. To do so, it presents a simple framework for understanding how this demand for environmental quality might have been met, which fits-in with Carson's (2010) proposal for a structural model of the factors determining environmental quality. It then reviews five episodes from British history of the demand for energy-related environmental quality and whether it could be or was met by low polluting energy sources.

The next section presents the conceptual framework outlining the demand for and supply of environmental quality and the cause of the market failure that implies that supply does not respond. This leads to a discussion about the process through which government can influence the supply to meet demand, such as encouraging the use of low polluting energy sources. It then identifies some reasons why government fails to act as a conduit between supply and demand. The third section reviews five historical cases where the energy-related environmental improvements were demanded. Section four discusses some insights from these experiences for a possible transition to a low carbon economy. The final section draws conclusions.

\section{Environmental "Markets" and Legislation}

\subsection{The Demand for and Supply of Environmental Quality}

One way to understand energy transitions to low polluting energy sources are by focussing on the role of changing dynamics of the demand for and the supply of environmental quality on energy markets (Pearson 1994, McConnell 1997, Kolstad 2006). Throughout history, and as will be discussed later, energy consumption has been responsible for a great deal of health and environmental damage. Some, observing these external costs and recording their scale, have demanded improvements in environmental quality (Brimblecombe 1987).

At a particular level of pollution, the higher are the marginal external costs or equivalently the marginal benefits of abatement, the more we might expect individuals to be willing to pay (or seeking other means, such as lobbying for legislation) for improvements in environmental quality. Plotting the marginal external costs associated with energy-related pollution or its equivalent as marginal benefits of abatement at different levels of pollution identifies the Demand curve for improvements in environmental quality (see Figure 1). The demand curve might be flat, implying the pollution generates the same damage and benefits of abatement at all levels of pollution. Alternatively, the demand curve might be downward-sloping, as in Figure 1, indicating that as pollution levels increase (i.e., a reduction in environmental quality), the marginal damage and benefits of abatement also increase. 
Through time, factors might change the related demand for this environmental quality. In Figure 1, these changing factors are reflected by a shift in the demand curve. It is important to appreciate that although, the marginal benefits of abatement might change, for, say, demographic or physical reasons, one might expect the impact of a pollutant on an individual's health to remain the same through time. Instead, much of the changing factors are associated with the perceived marginal benefits of abatement.

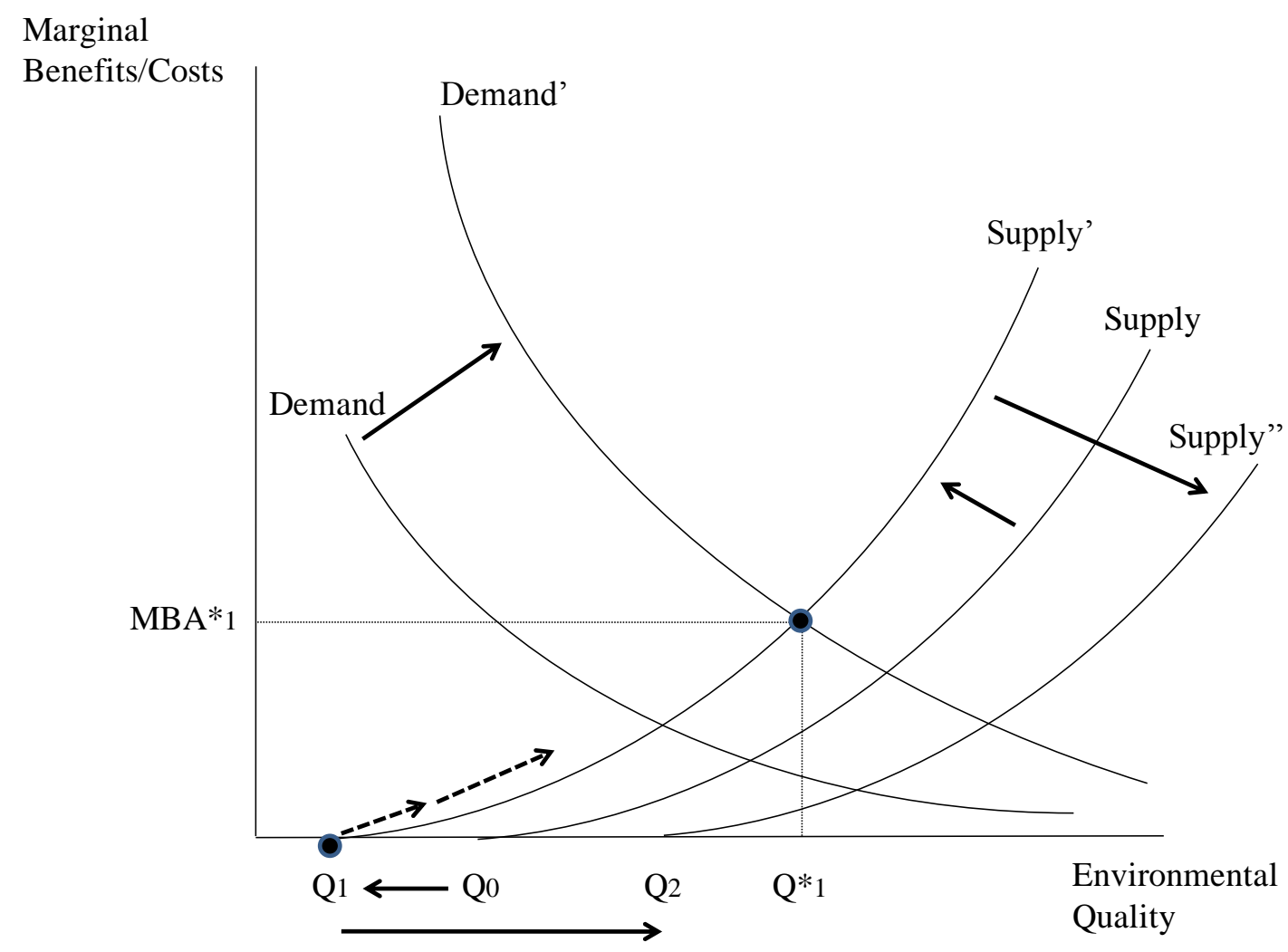

Figure 1. The Demand for and Supply of Environmental Quality

First, as income rises, households have more time and money to be concerned about the environment - that is, there is a 'positive' income elasticity for the environment. Second, although there is limited evidence of this, as income rises, households may be more concerned and interested in the environment - a 'greater than one' income elasticity for the environment (Dorfman 1977). In fact, there is evidence that in certain cases, income elasticities for environmental quality are relatively low (Kristrom and Riera 1996, McConnell 1997). However, it does appear that when an economy is in a recession, environmental concerns decline, as economic and other social issues take priority. Thus, in the short run, demand might be quite unstable, shifting with the business cycle.

Third, possibly helping to justify the existence of higher income elasticities is the fact that communities with higher incomes tend to have a greater awareness, information, education and 
knowledge of environmental pollution, risks and hazards. This often drives the introduction of more stringent environmental legislation (Dasgupta et al 2002, Kahn 2002). Brasington and Hite (2005) examined the relationship between the price of housing and environmental quality, and found that price elasticity is relatively small, and propose that this result indicates either that people are not very sensitive to changes in the price of environmental quality or they cannot easily respond to changes in environmental quality, as it depends on public decisions or moving. Thus, fourth, more open and democratic political systems should be more willing to reflect the concerns and sufferings of the public (López and Mitra 2000).

The supply curve reflects the marginal costs of abatement. Generally, these costs of abatement are expected to rise as pollution declines, suggesting that when polluters reduce emissions, they seek the cheapest options first. Just like demand, through time, the "supply" of environmental quality may shift - as in Figure 1, from Supply to Supply'. The existence of a demand for and supply of environmental quality (or at least, for improvements in environmental quality (McConnell 1997)) suggests the potential for a social optimal level, identified in Figure 1 by the meeting, at $\mathrm{Q}^{*} 1$, of the demand (Demand') and supply (Supply') curves.

The factors shifting the supply may worsen or improve the level of pollutant emissions and the ability of waste receptors to deal with these emissions. First, economic development has been associated with a shift from agriculture to heavy, then light industry, and finally services. Each of these sectors required different energy services, different energy sources and imposes different environmental damages (Mosley 2010). Second, as more 'cleaner' technology is produced and used, unit costs may fall. If increasing returns to scale do exist, wealthier countries, because of greater investment in pollution abatement, can reduce emissions more cheaply (Andreoni and Levinson 2001). It also suggests that, at the same stage of economic development, current developing economies might also have access to cheaper abatement technologies than today's developed economies. Third, polluters (whether individual agents, cities or countries) can export their emissions, either to uninhabited or poorer areas and countries; this is a broader version of the 'pollution haven' hypothesis (Cole 2004).

Finally, transitions in energy sources used (e.g. from biomass to coal to petroleum to gas) have frequently, and often coincidently, had a lower or higher impact on the environment. At times, however, this transition may not have been coincidental and may have depended on the influence of demand for environmental quality. This demand might generate a demand for energy sources causing little pollution. This links the "markets" for environmental quality and energy, and is central to this paper. In Figure 1, substitution to low polluting energy sources might be seen as an additional shift in the supply curve, from Supply' to Supply'.

Certain minor incentives encourage polluters to reduce the external costs of their pollution. First, a consumer's use of energy is likely to be somewhat inefficient. Better resource management reduces 
costs and pollution at the same time. But, these incentives only imply that they will reduce pollution as long the costs (of abatement) are negative (i.e., the private benefits outweigh the costs). Second, a consumer may be image-conscious. An individual may concerned about his/her social status, and using "inferior" or the "wrong" equipment, technology or energy source may be an undesirable signal to send. Similarly, a company may realise that its product differentiation and ability to sell its product is in part dependent on the image it portrays in relation to environmental care and how shareholders, employees, contractors and consumers perceive it (Blacconiere and Patten 1994). In Figure 1, the incentives are represented by a short dashed arrow (along the Supply' curve), and the outcome is a slightly higher level of environmental quality. While this conspicuous consumption may drive certain (niche) consumers to reduce emissions, it cannot be expected to generate much abatement, without additional incentives, such as prices or punishment.

In general, since the costs of pollution are incurred by society (as damage to health, natural ecosystems, etc..), the energy consumer has tended to ignore these external costs when deciding how much to consume. The consequence is that the demand for and supply of energy (or other goods) generating negative externalities has tended to be too high. From an environmental perspective, a socially insufficient level of environment quality is provided - in Figure 1, perhaps a little more than Q1 but certainly much less than Q*1 (Buchanan 1968).

\subsection{The Supply of Environmental Legislation}

It has been suggested that, since the external costs associated with energy consumption are not fully taken into account, the market for environmental quality fails to develop properly. The inability to directly signal preferences to the supply side creates a demand for environmental legislation, which can in turn influence supply. The combination of legislation and the threat of enforcement might create incentives for externality-generating agents to internalise them, and improve the supply of environmental quality, towards the optimal level where demand and supply meet.

The supply of environmental legislation can be considered a many-step process - the first two steps are the proposal and the vote. First, government makes a proposal about the appropriate level and the institutional framework (i.e., instrument choice) to ensure supply side adjustments to the demand for environmental quality. Then, in parliament, a vote is made to decide whether the proposal should be accepted or rejected, possibly subject to amendments. Both the proposal and the vote can be considered the outcome of the interaction of the demand (from the public and various pressure groups) for and the supply (by policy-makers and politicians) of environmental legislation (Keohane et al. 1998). In a democratic political system, if a proposal is made and sufficient politicians vote in favour of the proposal (often in two votes, in the lower house (e.g., Commons or Representatives) and the Upper House (e.g., Lords or Senate), then the legislation can be introduced. 
Once the legislative framework is set-up, there is a need for monitoring and enforcement. This may often be provided by a regulatory body (e.g. most recently, an environment agency). Often this authority may have other roles, in addition to this one and, therefore, determines the amount of effort that it will provide to monitoring and enforcing. This will depend on resources available (e.g., members of staff and equipment for the tasks), the pressures to provide the service, and other similar costs and benefits as the politician, including ideological beliefs and lobbying.

If the authority does monitor and enforce, it ensures that the constraints imposed on economic agents are binding. As a consequence, the supply of environmental quality adjusts, hopefully, towards the equilibrium with the demand (in Figure 1, this is represented by another dashed arrow or a shift in the supply curve, to Supply"). The stronger is the monitoring and enforcement, the more likely the policy is going to actually influence the supply of environmental quality; without sufficient threat, supply cannot be expected to meet the demand. In many cases, major polluters will not necessarily be included in the legislation and, therefore, pollution is improved only a little towards its optimal level.

Finally, even if legislation has been introduced, enforced, monitored and captured all the relevant polluters, a future government may seek to overturn the legislation. Again, this over-turning will need to follow a similar process, although, this time, it would receive the backing and lobbying from groups that have experienced financial losses from the original legislation. Especially, in times of economic crisis, many may consider the financial and economic benefits (over overturning the legislation) to outweigh the health and social benefits. Thus, to keep the environmental legislation requires a strong and sustained demand for environmental quality and for legislation.

\subsection{Government Failures in Environmental Legislation}

While the public may value improvements in environmental quality and be putting considerable pressure on politicians, there exist many factors that may lead to 'government failure', such that the market for environmental quality remains either not regulated or sub-optimally regulated.

First, as mentioned above, pressures on politicians may sway decisions away from the ideal plan. Politicians within government are pursuing their own objectives (Breton 1974). The government acts as a temporary monopoly supplier, enabling politicians within to use this position of power to combine public goods, such as the regulation of environmental pollution, with private goods that may, for example, assist in achieving their personal objectives. For example, decisions may be guided by an attempt to win votes, possibly from a strategic minority (Buchanan and Vanberg 1988, Boyer and Laffont 1999) or to appease powerful lobbies with stakes in the outcome of policy choice (Fernandez and Rodrik 1991, Dijkstra 1999) or even to avoid bad press associated with policies that might harm the low-income groups more than proportionally. So, while the government decides what its outputs will be and in what quantities, it is open to influence about these decisions. Many different pressure 
groups are likely to want to influence the decision-making process, including company managers, shareholders and employees from many different industries (either as consumers or producers of energy), trade unions and environmental organisations, etc... Their influence on the likelihood of legislation and the type of instruments used will depend on the power of each pressure group, the coalitions formed amongst them and the methods of influencing. One can expect that, at a given level of pollution, the higher the marginal benefits of abatement (e.g., Demand' at Q1 (i.e., roughly the current level of pollution) in Figure 1), then the greater will be the lobbying for legislation, and the higher the marginal costs of abatement (e.g., Supply' at Q*1 (i.e., the possible target for environmental legislation)), then the more intense will be the counter-lobbying against legislation.

Second, the costs and complexity of producing, distributing and assessing scientific or other information can hinder regulators' ability to identify the optimal level of environmental quality. Environmental pollution and the attempt to minimise its consequences raise great uncertainties, which can be reduced through information collection and analysis. Since resources are limited, a trade-off between expenditure on information and on action must be made. Insufficient funds allocated to information will mean an excessive level of uncertainty remains, hindering the potential for action. Excessive expenditure for information will leave implementation underfunded or delayed. Also, misallocation of resources between these two activities will reduce overall policy effectiveness (Brunner and Klein 1999). Furthermore, as scientific information passes from the need to reduce uncertainty about a problem, into the market for scientific analysis with opaque methods of allocating resources and the incentives of researchers, and then into the world of media, it is unlikely that valuable, non-controversial knowledge will have been generated and used through the most efficient allocation of funds (Stevens 1996). Nevertheless, new scientific understanding and its media coverage can radically alter public perception of the pollution, potentially shifting the demand to the right in Figure 1. Similarly, new technological developments can reduce the marginal costs of abatement, shifting the supply curve to the right.

Third, bureaucracy may also limit the socially optimal decision-making of government. Although government makes the decisions, most of the funds are channelled through civil servants hands, who have their own objectives (Niskanen 1971). Each department or bureau receives funds reflecting a perception of its output - the society's benefits increase with the department's output, but at a decreasing rate. It incurs costs, which like assumptions about other organisations tend to increase more than proportionally as output increases. Ideally, the government should increase fund provision to the department until the marginal benefits equal the marginal costs. In this market for the administration and implementation of regulation, the outcome will be the result of interaction between supply (e.g., the Ministry of Health or Environment) and demand, that is, the government (Breton and Wintrobe 1975). Because of government's inability to correctly estimate this level and one of the bureaucrat's key objectives being to maximise budget size, the government will tend to over-fund 
departments, reducing the efficiency of policies. Furthermore, either because internalisation is considered of secondary priority, departments may clash over objectives (Oates and Strassman 1978) or the personality of civil servants driving policies are weak (in comparison with those responsible for other policies), funds and activities are inefficiently allocated. Finally, the high costs and complexity of implementation, monitoring and enforcement may also hinder progress towards legislation.

\section{Historical Demand for Environmental Quality and Legislation}

This section reviews five episodes in British history (the seventeenth century (3.1), the Victorian era (3.2-3.4), and the early- (3.5), mid- (3.7-3.8) and late-twentieth century (3.9)) where a demand for air pollution improvements existed, in order to identify the demand's influence on the supply of environmental legislation and on transitions to low polluting energy sources.

\subsection{Fumifugium in the Seventeenth Century}

In the seventeenth century, coal consumption in London had been growing rapidly (see Figure 2). The transition from woodfuel to coal had begun in London in the sixteenth century as chimneys and grates were being introduced and refined, a reliable coal trade from the North-East of England developed, and the difference between the local price of coal and woodfuel increased (Allen 2012, Fouquet 2011a). The growing population and expanding economy of London created a rising demand for heating fuels, increasingly met by the coal trade.

This increase in coal combustion led to a growing air pollution problem in London, which was highlighted by a number of gentlemen associated with the Royal Society (Brimblecombe 1987). Most famously, John Evelyn, in his pamphlet Fumifugium, argued that the smoke associated with coal burning, particularly related to industry, was harmful to the population. Indeed, he points-out that, during the English Civil War (1642-46), the coal trade was severely disrupted, coal prices soared, and London air quality improved greatly (Evelyn 1661 p.21). He proposed that London should be redesigned, forcing polluting industries (such as brewers, dyers and lime-burners) to be based at sufficient distance from the population (Jenner 1995). Also, efforts should be made to ensure a cheap supply of woodfuel to households to reduce air pollution (Brimblecombe 1987 p.49).

Coal producers, merchants and consumers of the time were a heterogeneous group with little coordination. Also, scientific understanding was in its infancy and John Evelyn was a member of the Royal Society, the bastion of natural philosophy and the height of scientific enquiry of the time. He was able to meet with King Charles II to discuss the problem. Thus, building on previous scholars studies, he required relatively little proof to convince his colleagues and the King of the problem of air pollution. In January 1662, “the Queen's Attorney sent Evelyn the draft "of an Act, against the 
nuisance of the Smoke of Lond, to be reformed by removing severall Trades, which are the cause of it, and indanger the health of the K: and his people, etc. Which was to have ben offerd to Parliament, as his Majesty commended.” (Bowle 1981 p.109).

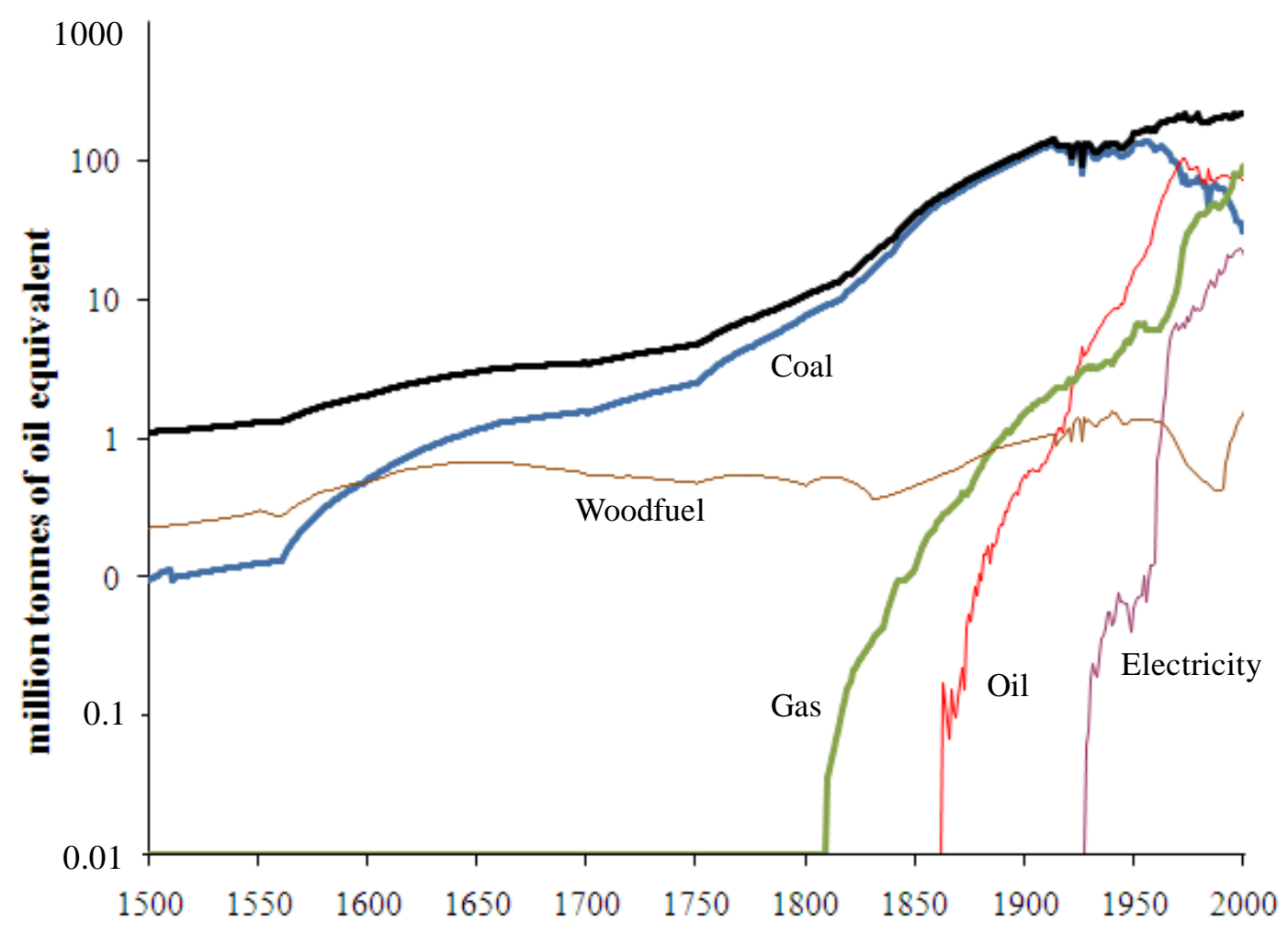

\section{Figure 2. Energy Consumption in the United Kingdom, 1500-2000}

However, there is no evidence the Act was passed. Furthermore, following the Great Fire of London in 1666, and the rebuilding of London, there was little effort to reorganise the city in-line with Evelyn's objectives or the proposed Act (Birmblecombe 1987 p.52). If it was introduced, the legislation probably would have failed to dissuade consumers given the advantages of coal over woodfuel in the capital. Inevitably, proposals to reduce pollution, as well as use more benign energy sources, were unsuccessful.

\subsection{The Demand for Air Quality in Victorian Britain}

Later, in the mid-nineteenth century, after a further two hundred years of growth in coal consumption, air pollution in London was becoming far worse. The problem was immortalised in the stories of Sherlock Holmes. The Adventure of the Bruce-Partington Plans began "In the third week of November, in the year of 1895, a dense fog settled down upon London. From Monday to Thursday I doubt whether it was ever possible from our windows in Baker Street to see the loom of the opposite houses." (Doyle 2003 p.412). When the fog descended, trains stopped running, court cases were 
abandoned, thieves prowled. The fog was coal smoke, which became trapped on windless days in the winter, when homes needed extensive heating, and the fog shielded the warmth from the sun. In the late nineteenth century, London averaged 80 days of dense fog per year! In parts of the city, such as West Norwood, in 1885, more than 180 days were recorded as foggy (Clay and Troesken 2010 p.62). The economic costs to London, and other major cities, grinding to a halt due to the fog are unimaginable.

The rise in smoke concentration has also been linked with the rapidly soaring mortality rate attributed to bronchitis - from 25 deaths 100,000 inhabitants in 1840 to nearly 300 in 1890 (see Figure 3). A conservative estimate of the annual health damage caused by coal production and consumption at the end of the nineteenth century was $£(2000) 20$ billion and close to $20 \%$ of the British GDP (Fouquet 2011b).

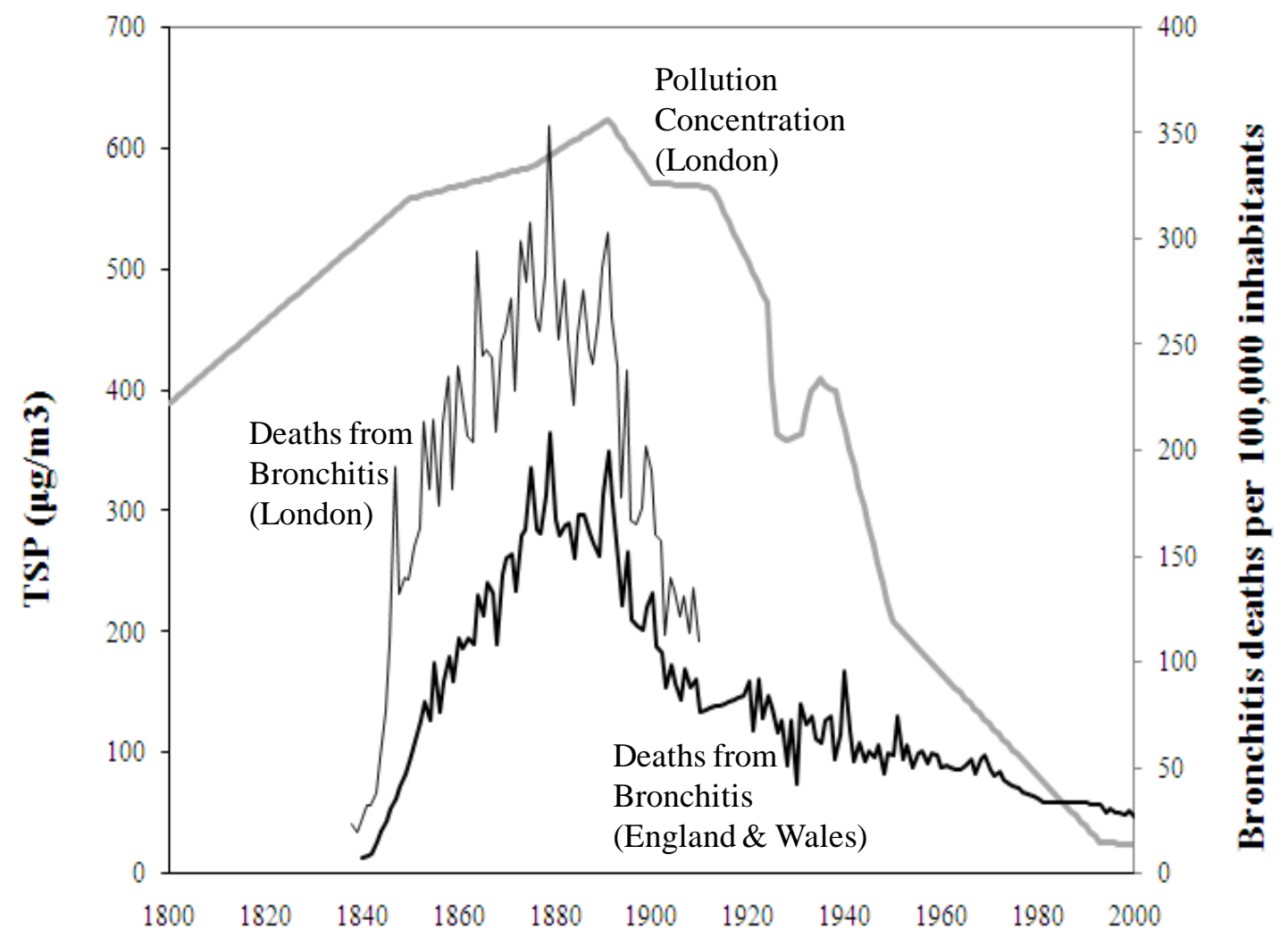

Source: Air Pollution: Brimblecombe (1987); Deaths: Registrar General (1838 onwards)

Figure 3. Air Pollution Concentration in London, and Mortality Rate attributed to Bronchitis in London and England \& Wales (1800-2000)

Despite the rapid rise, many dissenters, possibly encouraged by industrialists fearing environmental legislation, questioned the harmfulness of air pollution. The miasma theory proposed that natural and biological decay caused impurities in the air, and smoke actually cleansed the air of these impurities. 
This only started to be formally rejected in the 1880 s, and a consensus formed about the health damage caused by smoke (Thorsheim 2006 p.195).

From the 1860s, the Smoke Abatement Societies in the major urban centres in Britain spearheaded the demand for improvements in air quality. These voluntary organisations were off-shoots of wider movements seeking to improve environmental conditions and concerned about public health, bringing together women, middle-class professionals and non-conformist Protestants, partly driven by a belief that the lower classes needed to be cared for and their behaviour controlled (Thorsheim 2006 p.80).

The highly concentrated pollution in Manchester led to the creation of the first Smoke Abatement Society. "During the 1870 s and 1880 s it sponsored public lectures, classes, and publications that were intended to educate the public about the benefits of clean air and to promote gas cooking and heating appliances in place of coal fires." (Thorsheim 2006 p.81).

The Smoke Abatement Societies across Britain tried to pressure succeeding governments into introducing legislation. They gained strength in the last couple of decades of the nineteenth century, when the damage done by air pollution was at its worst (see Figure 4), and their pressure mounted.

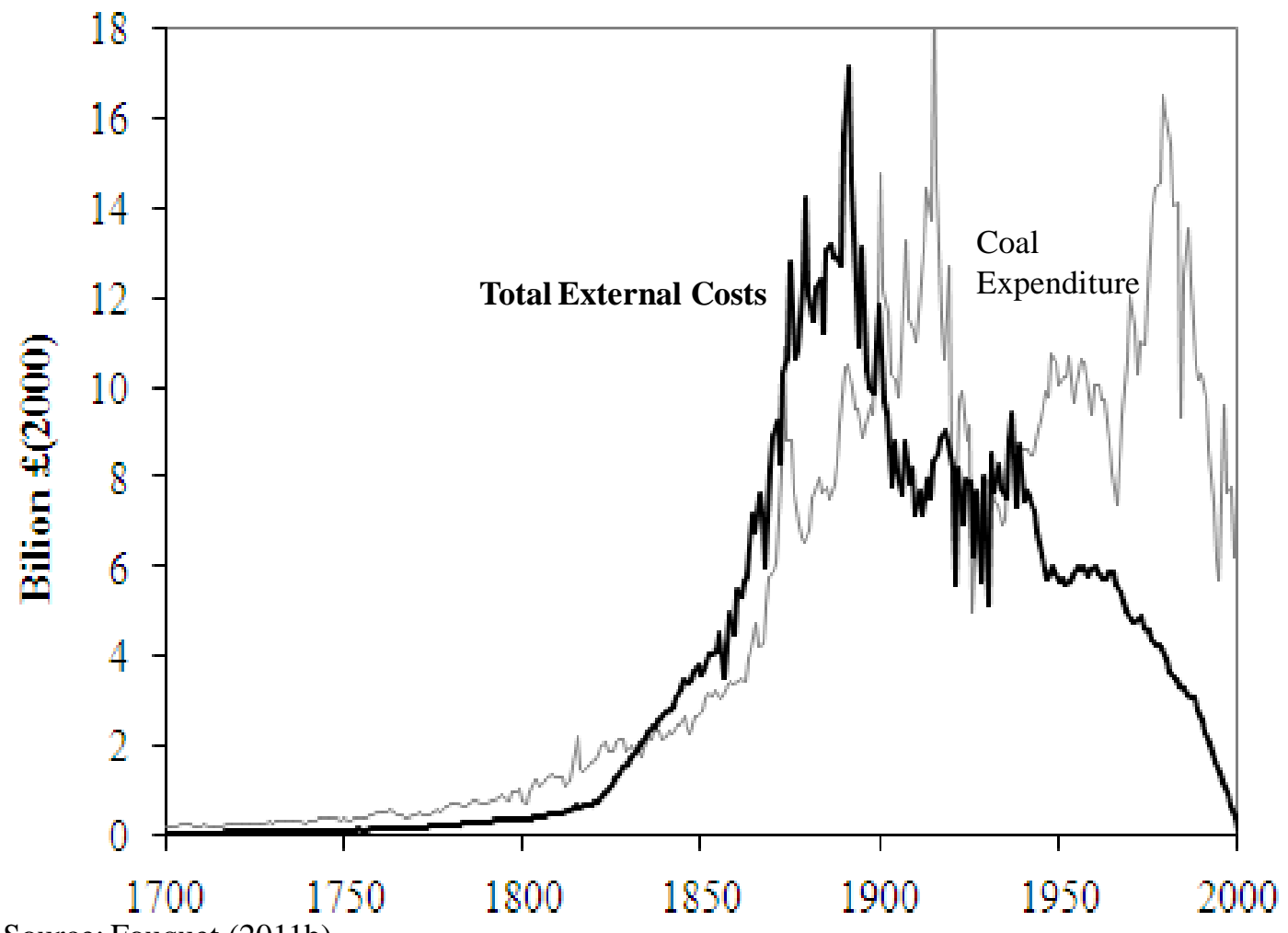

Source: Fouquet (2011b)

Figure 4. Estimates of the Total External Costs of Coal Production and Consumption, compared with Expenditure on Coal, 1700-2000 
As early as the mid-nineteenth century, numerous solutions existed to help mitigate air pollution: businesses knew that good stoking was the key to both using coal efficiently and reducing smoke emissions (Thorsheim 2006 p.18); Continental and Scandinavian homes had used far more efficient stoves for heating at least since the eighteenth century (Fouquet 2008 p.79); gas cookers began being used in the 1840s, and there was extensive gas supplies in all towns across the country (Goodall 1999 pp.24-9); there were other smokeless fuels, such as anthracite coal (available in the South West of Wales) and coke (produced by carbonising the coal first), that could have been used by households for heating purposes (Jevons 1865 p.156); and, railroads could have expanded the limits of the city, spreading the air pollution and reducing concentration (Jackson 2003). So, opportunities for mitigation existed. The question was whether there was the political will to reduce emissions.

\subsection{Legislation against Industrial Pollution}

The economic imperative meant that it was hard to deny firms the right to produce. A common approach to the pollution problem in the nineteenth century was containment. Rather than banning activities, they were tolerated where they already existed. This meant that polluting industries concentrated in particular areas, generally working-class areas, and ensured that middle-class suburbs and countryside were unharmed by industry's expansion.

From the 1840s, a more interventionist approach began. For instance, the Police Act introduced in Manchester led to the fining of thirteen cotton mills in 1845 . However, they were only fined $£ 2$ each (Mosley 2001 p.144). Needless to say, such 'powerful' incentives failed to alter the behaviour of industry and it continued to pollute where it could. This example reflects the concern that imposing heavy fines would harm industry, reducing employment and competitiveness (both at a local and national level). This was the beginning of a very long process of balancing the need to discourage polluting and the need to avoid imposing excessive costs on economic activities.

In 1843, after extensive political struggle, a Parliamentary Select Committee on Smoke Prevention was formed. It was an acknowledgement of the national government's responsibility to address the problem. It was also one of the first uses of scientific expertise to inform government on the appropriate action. The problem was taken sufficiently seriously to draw upon Sir Thomas Henry De La Beche, Director of Geological Society, and Professor Lyon Playfair of the Royal Manchester Institute, and calling upon eminent scientists, such as Michael Faraday (Whiteread 2011).

The Smoke Nuisance Abatement Act of 1853 introduced legislation to fine factories that emitted excessive smoke in London. During the first few years, the police was actively and aggressively involved in enforcing the law - with hundreds of cases. However, enforcement was inconsistent and the fines were very low - generally, less than one pound. Furthermore, with time, enforcement waned, and by the 1870s, the law was ignored (Thorsheim 2006 p.112-3). More generally, many towns and 
cities across Britain were reluctant to take much action as many officials believed that punishing industry would drive manufacturers to less stringent locations (Thorsheim 2006 p.119).

In 1863, the Alkali Act, seen as the first national environmental legislation, was introduced. It was also innovative because manufacturers' activities, in particular, the chemical industry, were monitored by the authorities in order to minimise the damage done by hydrogen chloride to landowners, particularly large and wealthy ones. "A conjunction of circumstances favoured its passage[:] ... a practicable technology was available, most manufacturers were amenable to some control, and an effective lobby existed to push for legislation" (Dingle 1982 p.546). In this Act, a specific industry was addressed, and a condensation process was available, relatively cheaply, to capture almost all emissions. Using new scientific equipment developed for the purpose, it was possible to monitor effectively individual polluters and force them to reduce emissions (Dingle 1982). Thus, it was the first great success in environmental legislation.

However, it failed to include emissions from coal combustion, despite strong efforts by prominent scientists Thorsheim 2006 p.113). Finally, the Sanitary Act of 1866 required (rather than allowed) municipal officials to prosecute owners of smoky businesses. Industrialists considered that legislation restricting emissions would impose unacceptable costs, and fought to defeat such parliamentary bills and to minimise the effectiveness when successful. Loopholes (related to wording of the act) and exemptions implied it was not enforced. The Public Health Act of 1875 (which did not apply to London) stated that smoke nuisances should be reduced "as far as practicable", and leniency was common. The Public Health (London) Act of 1891 introduced equally weak and lenient legislation to the capital, only addressing certain businesses (Thorsheim 2006 pp.113-5). Another example of the power of wording in legislation was the introduction of the term "black" smoke into legislation: it meant that only "black" smoke could be prosecuted against. It took until 1926 for legislation to address non-black smoke, but, even then, each case needed to receive approval from the Ministry of Health. Thus, into the 1950s, legislation on industrial pollution continued to be heavily flawed (Thorsheim 2006 pp.131).

Furthermore, officials and magistrates in local authorities, who were responsible for prosecution, were reluctant to enforce legislation. The London County Council, which was more interested in reducing emissions but with no immediate power, noted over 9,000 failures to prosecute air pollution infringements between 1892 and 1904. A survey of local health boards across Britain in 1886 gives clues to the problem, as it indicates that nearly one-fifth of the members on the boards were in manufacturing (Thorsheim 2006 pp.115-8). Thus, those that were likely to suffer most from environmental legislation found ways to influence politicians that were drafting legislation and making decisions about it, and to be in positions to minimise their enforcement. 


\subsection{Adaptation as a Solution to Environmental Problems}

As mentioned above, by the mid-nineteenth century, there were a number of solutions to reducing pollution emissions or concentrations. The main solutions were for consumption to become more efficient, switching to less polluting energy sources or exporting the pollution. Smoke abatement societies had put pressure on government, and legislation had been introduced. Unfortunately, it was relatively weak and poorly enforced, especially in the long run.

Nonetheless, in the 1890s, the air pollution problem in London (and in other cities) was partially resolved. While still high by twenty-first century standards, air pollution concentration halved over the next fifty years, dropping below $300 \mu \mathrm{g} / \mathrm{m} 3$ (see Figure 2). Fouquet (2011b) argued that the main explanation was not fuel switching, as coal consumption and emissions in London continued to increase between 1890 and 1910. It was probably not energy efficiency improvements either. Although the efficiency of many technologies did improve substantially during the second half of the nineteenth century, income and price elasticities appear to have been very high (Fouquet and Pearson 2012). In other words, efficiency improvements most probably led to large rebound effects, ultimately increasing coal consumption, as Jevons (1865) had predicted.

Instead, the main explanation was the suburbanisation of British cities with the advent of commuter railways. The urbanised area of London increased five-fold between 1841 and 1901, halving the population density, which then declined a further three-fold between 1901 and 1951 (Demographia 2011). This enabled the population to live less densely and dilute the pollution concentration.

This could be seen as a form of adaptation to the environmental problem, which led inadvertently to improvements in conditions. But, it was an adaptation to a broader series of social and environmental problems, rather than just to air pollution. During the second-half of the nineteenth century, uppermiddle class families sought to live away from the crime, sewage and smoke that engulfed Victorian cities (Luckin 2000). Over the decades, they moved away. The introduction of the Cheap Trains Act of 1883 and a rapid expansion of suburban housing in the 1890s allowed a larger proportion of the population with more modest means to live in the suburbs and commute into the city, leaving the poorest in the centres (Thompson 1982, Jackson 2003, Burnett 1986).

Effectively, the demand for urban improvements increased during the second-half of the nineteenth century, and transport and housing markets reacted, although slowly, to the demand. It took them around fifty years to adapt to the demand for improvements in social and environmental quality, and the market outcome was to export pollution (to the suburbs), rather than reduce it. This was not necessarily a desirable long term solution - as was discovered at the end of the twentieth century, when it continued to be a problem in the form of acid rain and climate change. 


\subsection{Demand for Low Polluting Energy Sources before 1950}

As suggested, energy markets were even less effective at responding to the demand for environmental improvements. With weak legislation, businesses and households had little incentive to reduce their smoke emissions. Although socially desirable, the free-rider problem hindered the evolution of the market for low polluting energy sources, thus, forcing individuals to "adapt".

Despite the market failure and the more minor role in improving pollution concentrations, it is worth examining the extent of the demand to switch to less polluting fuels. That is, some consumers may still have been willingness to pay for low polluting energy sources.

If consumers sought cleaner fuels, they had the option of using anthracite coal, coke, gas and later electricity. Anthracite coal was of particular value for households as it was clean to handle, producing no dust or smoke. "It burns very slowly and never requires poking or attention, except to replenish the stove" (Jevons 1915 p.660). Welsh (steam and anthracite) coal was roughly 20\% more expensive than standard coal (Clay and Troesken 2010 p.48). Nevertheless, the doubling of anthracite coal consumption in Britain between 1894 and 1913 - total coal consumption increased 45\% (Jevons 1915 p.665) - may have been influenced by the rising demand for smokeless fuels.

Interestingly, British behaviour was still not in-line with other countries. On the continent, the use of stoves had encouraged the consumption of anthracite. For example, it was sold in Paris at $£ 3$ per ton equivalent to $£(2000) 300$ per tonne (Jevons 1915 p.666) - three times the average price of standard coal in Britain. In 1915, more than half of the United Kingdom's production of anthracite was for export, where as it was around one-third for other forms of coal.

An alternative to anthracite was coke, often the by-product of creating gas from coal, but also a crucial fuel in certain manufacturing processes, such as in iron smelting. Coke was also smokeless at use. However, by consuming coke (or gas) much of the problem was shifted to the source of production. Nearby residents "complained that its fumes harmed plants and trees, sullied clothing, tarnished brass and copper, discolour paint, and impaired health... Over time, such localities became occupied almost exclusively by poor and working-class people who rarely possessed sufficient economic, political or legal power to challenge polluters' activities" (Thorsheim 2002 p.386).

Coke production nearly tripled between 1890 and 1910 (Church 1986). It is hard to attribute the source of demand. But, since the iron and steel industries energy consumption only increased by $15 \%$ in that period, it is probable that a great deal of households began to use coke for heating and cooking purposes at the turn of the century. Thus, it might have helped alleviate the pollution problem. However, the nature of coke and gas production implied that neighbourhoods near the production site suffered even more pollution (Thorsheim 2002). 
Driven by the gas companies' initiatives to find new markets following competition from electricity in the lighting market, there was a rapid uptake of gas cookers from the 1890s. The Gas Light \& Coke Company, which supplied two-thirds of London customers, noted that in 1892 only $2 \%$ of its customers had gas cookers and, by 1911, 69\% had them (Goodall 1999 p.105). In other words, nearly 500,000 households in London (or more than half the homes in London) had gas cookers. An impressive, if slightly more modest growth was seen across the country - in Britain, by $1898,20 \%$ of gas customers, equivalent to $6 \%$ of households in the country. This increased to $42 \%$ of British gas customers (or roughly 26\% of all households) in 1914 (Goodall 1999 p.106). The popularity of gas cookers continued to grow. By 1940, 3.5 million gas cookers had been sold (Goodall 1999 p.107).

Interestingly, by $1905,22 \%$ of municipal customers had gas cookers, while $42 \%$ of private customers had cookers. Over the next ten years, private companies increased the gap - in 1914, 35\% of municipal prepayment customers had gas cookers, while $57 \%$ of private prepayment customers had cookers (Goodall 1999 p.106). This institutional difference continued for decades: in the 1920s and 1930s, annual gas cooker sales were consistently one-third greater amongst private customers as municipal customers (Goodall 1999 p.107). Thus, these gaps show the clear failure of government to promote low polluting energy sources at a time when it was desperately needed, and that private enterprise was more effective at promoting a transition.

While gas cookers were competitive and cleaner, and reflected a more modern lifestyle, gas heating was still three times more expensive than anthracite coal (Jevons 1915 p.666). Much of the coal household demand, especially on cold days when the heavy fogs occurred, was not for cooking but for heating. Indeed, total coal consumption (excluding the coal used for gas works) in London still increased by 12\% from 1890 to 1910 (see, for instance, Clay and Troesken 2010 p.71) - implying that total emissions rose, as well. Nevertheless, it is important to note that the increase in consumption of low polluting energy sources may have helped avoid a worse "business-as-usual" counterfactual. After all, between 1890 and 1910, national population increased 19\%, per capita GDP 13\%, and coal prices stayed relatively constant (Fouquet 2008). Thus, given the probable high income and price elasticities at the turn of century (Fouquet and Pearson 2012), coal consumption and emissions might have been expected to increase substantially more than $12 \%$.

Later, in the 1930s, electric cookers was seen as the height of modernity and their use took-off, increasing from 210,000 in 1932 to 1.5 million in 1938 (Bowden 1988 p.44). Part of this increase was driven by accessibility to electricity. In 1932 , only $31 \%$ of the housing stock had access to electricity; by 1938, 65\% were wired (Bowden 1988 p.44). Nevertheless, the proportion of wired-homes using electric cookers rose from $5 \%$ to $17 \%$ (or $1.5 \%$ of all homes to $11 \%$ ) in that time. Also, rising incomes helped boost demand, as electric cookers were seen as the more advanced than gas cookers given that only wealthier households were able to afford to use electric cookers, they were probably 
substituting away from gas (rather coal and its derivatives). During the 1930s, electricity prices fell $35 \%$, while gas prices increased (Fouquet 2011a). Thus, this new demand for a low polluting energy source was driven probably more by economic forces, convenience and status, than responding to a demand for environmental quality.

\subsection{The Evolution of Government on Environmental Legislation}

Historically, the British government had tended to avoid involvement in industrial activity or meddling in domestic affairs. The latter would have represented an invasion of personal liberties, and the former was appropriate only when absolutely necessary. The dominant economic ideology within government before the twentieth century was relatively laissez faire within Britain, apart for the growth of fiscal intervention to support the public budget and debt. This ideology, in part, reflected those in power, landed gentry and increasingly entrepreneurs and merchants, who benefitted most from the lack of government involvement in economic affairs. Thus, one of the main perceived functions of government was to protect private property, but not to interfere in its use (Thorsheim 2006 p.110).

However, the role of government began to increase from the 1830s, as it was seen that if property was damaged without consent by others' behaviour, there might be grounds for government intervention. Traditionally, victims of pollution had the right to seek compensation for the damage caused by the perpetrator, either in Coasian negotiations or through the courts. However, the expansion and increasing concentration of industrial activities made it difficult to undertake such costly negotiations and prosecution. "Early environmental legislation was ... justified by the argument that state intervention was necessary in cases where it was impractical for individuals to identify and hold responsible the particular firms that were causing harm to property", such as the Alkali Act of 1863 (Thorsheim 2006 p.111).

Another important change in the role of government followed the First World War. The government's strategic interests led it to become heavily involved in many aspects of economic and social affairs that were previously seen as beyond its remit. It also started to develop a more analytical approach to problems. This included its role in directing energy policy to reduce air pollution (Thorsheim 2006 p.129).

With this changing role and greater analysis of government came an increased need for expert advice. Before the mid-nineteenth century, science had often been seen as unimportant, and not directly relevant to public affairs. It started to be used to advise in public health issues, such as their use for evidence by the Select Committee on Smoke Prevention in 1843. Nevertheless, their active involvement in directing policy was much slower, and only became more common in the twentieth century (Thorsheim 2006 p.129-30). Without these major changes in political involvement and 
understanding of problems, it is unlikely that government would have acted as a conduit between the demand for environmental quality and the supply.

\subsection{The Big Smog and High Polluting Energy Sources}

Conditions by the mid-twentieth century were much improved, compared with fifty years earlier. Average air pollution concentration had fallen below $200 \mu \mathrm{g} / \mathrm{m} 3$ (see Figure 3). Foggy days were occasional and shocking, rather than part of everyday life. Severe air pollution was less acceptable then, than it had been in the nineteenth century. One could argue that, perhaps as a result of rising income or greater awareness of the health impacts, the demand for environmental quality had increased considerably by the mid-twentieth century.

Starting on 5th December 1952, cold and windless weather patterns trapped smoke over London for almost one week. The cold weather increased the number of domestic fires; the resulting smoke stopped sunlight from providing natural heating, thus, requiring more coal to be burnt. The intense fog led to many respiratory problems, especially amongst the young, the weak and the aged.

The Big Smog shocked the nation. The ministry of health downplayed the event, blaming influenza and already weak victims - it initially suggested that 2,851 people died from the fog. Its attitude was to feel that the fogs had been happening for centuries and it had little role to play. In the months following the event, the government was severely criticised for its indifference, despite some warning that this could happen again. Seven months later, the Beaver Committee was formed to investigate the event - the official number of deaths was eventually placed at 3,000-4,000 (Thorsheim 2006 p.163-6). However, one recent study of the event estimated that the air pollution may have led to an additional 12,000 deaths - including long term effects, yet excluding those associated with influenza and the cold (Bell et al 2004).

One potential aggravating factor was the type of coal used. In the winters of 1946-7 and 1950-1, the coal industry, run as a monopoly by the National Coal Board, faced major crises. Unable to supply enough coal for the demand, it began to ration. In 1951, trying to prioritise needs for electricity supply, it limited industrial consumption to $85 \%$ of normal use, it demanded that 3,000 passenger railway services be cancelled, and it rationed most households to $8 \mathrm{cwt}$ (roughly 400kg), although in Southern England, they were limited to $6 \mathrm{cwt}$ (about $300 \mathrm{~kg}$ ) of coal for the months of January and February (Jackson 1974 p.73).

The National Coal Board had been criticised for not supplying enough fuel to heat homes. It planned to keep rationing until 1958. However, prior to the season of cold weather, it organized an intensive advertisement campaign to encourage the use of "nutty slack" coal for domestic heating and, on the 1st December 1952, it would stop rationing its use. Nutty slack was a mix of small lumps of coal and 
dust. It was dirty to handle, produced a lot more smoke, but it was cheaper. It was 20 shilling per ton (i.e., 30\%) cheaper than standard coal (Thorsheim 2006 p.161-2). Although it is difficult to find estimates of household consumption, in five years, between 1948 and 1953, the consumption of "slack" coal increased 25\% and increased its share of total UK coal consumption from $34 \%$ to $39 \%$ (Ministry of Power 1961 p.72).

To minimise or avoid future similar episodes, the Beaver Committee highlighted the need to warn the public, advise vulnerable populations and maintain the use of smokeless fuels. The final Beaver Committee report in late 1954 proposed the creation of a Clean Air Act which included domestic, as well as industrial, pollution (Brimblecombe 2006).

\subsection{The Clean Air Act and the Shift to Low Polluting Energy Sources}

The Clean Air Act specified "black" areas, where the problem was most acute and smoke control programmes were most important. All areas in Greater London were designated as "black" areas and, generally, required controls. In the North West of England, 95 of the 151 areas were either "black" and/or to be controlled (Scarrow 1972 p.264).

In controlled areas, smoke emitting fuels, principally coal, was banned and smokeless fuels needed to be used for heating instead. Until then, the main cause of local air pollution, households, had remained an uncomfortable issue. The Clean Air Act required the conversion of domestic fires where pollution was a problem. It also involved inspection beforehand to identify the extent of the conversion needed and then afterwards to ensure the conversion was done properly.

A number of factors influenced a borough's progress towards meeting the requirements of the Clean Air Act of 1956. These were a borough's wealth, a perceived need for improvement in air quality and mining areas. First, the conversions and the inspections were very costly for local authorities. Wealthy "black" areas consistently made better progress towards meeting the targets for compliance with the Clean Air Act than poorer areas (Scarrow 1972 p.267). Second, the nine boroughs with the highest rates of bronchitis mortality in Britain had a median progress (towards compliance with the legislation) of $46.3 \%$, while the boroughs with the lowest rates had a progress of $19.4 \%$ (Scarrow 1972 p.277). Finally, mining areas tended to be reluctant to introduce changes as this was a politically sensitive issue.

It is valuable to consider the environmental and health impact of the Clean Air Act. From 1958 to 1965, smoke concentrations improved greatly - in London sites, a 60\% reduction, and in other sites, $27.5 \%$ (Scarrow 1972 p.272). Crucially, by the mid-1960s, weekly mortality and illness rates stopped varying with air pollution concentration, as they had before 1960 (Scarrow 1972 p.273). Another of the noticeable effects of better air quality was greater sunshine. During the months of November, 
December and January in the 1960s, inner city London had 55\% more sunshine than in the same months between 1930 and 1960. Interestingly, this would probably have helped reduced energy consumption associated with space heating and lighting (Scarrow 1972 p.273).

However, the improvements that were observed in the early 1960s may have been the acceleration of a larger trend. Air pollution concentrations had been falling since 1900 (see Figure 3). Similarly, energy consumption patterns in the second half of the twentieth century were also changing. "The new affluence ... in postwar Britain ... resulted in a demand for higher heating standards, viz., the cleaner systems which solid smokeless fuels introduced, and the labor-free, automatic, multiroom, and total-building heating systems associated with electricity, gas, and oil." (Scarrow 1972 p.275). A survey of households in 1961 found that space and higher standards of heating were the most important features to improve in homes (Scarrow 1972 p.275).

In addition to rising income and changing consumer preferences, energy supply companies played an important role in first delaying and then accelerating the transition. After the Clean Air Act was passed, the National Coal Board introduced an advertisement campaign promoting the "cosy coal fire" to discourage a shift to oil, gas or electricity. Local coal merchants also tried to oppose and delay local authority efforts to comply with the Clean Air Act (Scarrow 1972 p.277).

However, gas manufacturers seeking the cheapest production fuel heavily affected the market for smokeless fuels. Traditionally, they had used coal to produce gas. As a by-product, they also produced coke, which could be sold as a smokeless fuel. However, in the late 1950s, they found that oil was cheaper to produce gas. This switch implied that there was a shortage of coke, officially announced in 1963. The National Coal Board failed to produce enough coke and other smokeless fuels to meet the demand, encouraging a switch to other non-solid fuels (Scarrow 1972 p.277).

Another important factor was the slum clearance programmes introduced from the mid-1950s. Between 1955 and 1970, 733,000 houses were demolished in London and other Northern "black" areas - equivalent to one-sixth of the homes in the highly polluted areas in 1970 (Scarrow 1972 p.276). These homes were replaced with central-heating system that rarely depended on coal.

Smokeless solid fuels enabled households and other building to comply with the legislation while keeping the conventional way of heating a building. Indeed, in 1950, before legislation was introduced, nearly $40 \%$ of the heating demand in London was met by other solid fuels, which were mostly smokeless. In other words, many consumers had already been willing to pay for the smokeless fuels before the Big Smog and the Clean Air Act. It is difficult to identify the premium they paid for smokeless fuels, but it was no doubt more expensive than standard coal. Yet, after the Clean Act, the share of coal and other solid fuels in London declined from $71 \%$ in 1950 to $24 \%$ in 1970 (see Table $1)$. 
Table 1. Non-Electric Energy Use for Heating in London, 1950-2000

\begin{tabular}{lrrrrrr}
\hline & 1950 & 1960 & 1970 & 1980 & 1990 & 2000 \\
\hline Oil & $10.7 \%$ & $26.7 \%$ & $46.9 \%$ & $27.6 \%$ & $14.3 \%$ & $4.8 \%$ \\
Gas & $17.9 \%$ & $16.7 \%$ & $26.6 \%$ & $65.5 \%$ & $85.7 \%$ & $95.2 \%$ \\
Coal & $32.1 \%$ & $16.7 \%$ & $3.1 \%$ & $0.0 \%$ & $0.0 \%$ & $0.0 \%$ \\
Other solid fuels & $39.3 \%$ & $36.7 \%$ & $21.9 \%$ & $6.9 \%$ & $0.0 \%$ & $0.0 \%$ \\
\hline
\end{tabular}

Source: GLA (2002) p.21.

Note: Electricity is not included because of the difficulty of separating consumption between heating and other services - its inclusion would only increase the decline in solid fuels.

In the 1960s, the biggest substitution was to oil - meeting nearly half of the heating consumption in London. However, the discovery of natural gas in the North Sea and the Oil Shocks led consumers to switch to gas - from 26\% in 1970 to $65 \%$ in 1980 and up to $85 \%$ in 1990 (Fouquet 2008).

\subsection{The Dash for Gas}

The tendency to export pollution, either by suburbanising British cities or creating smoke-less zones and higher industrial chimneys, meant that emissions were not always discouraged. Nevertheless, from the mid-twentieth century, as the British economy moved away from heavy industries and made the transition from coal towards petroleum (see Figure 2), emissions did decline.

Nevertheless, coal consumption was crucial for power generation and was still responsible for sulphur dioxide emissions that were associated with acid rain. Due to prevailing winds, acid deposition occurred in the Highlands and Scandinavia, increasing acidity in lakes and forests, killing certain plants and animals, and corrosion of buildings.

In the 1980s, much of the pressure to set target reductions in emissions came from other countries. This included the Scandinavians (who were concerned about British acid rain harming their lakes and forests) and the West Germans (who had introduced Flue Gas Desulphurisation units on their coalburning power stations to reduce emissions, raising the price of generating electricity and, thus, reducing the competitiveness of their products). This international pressure led to the creation of an international convention. The Convention on Long Range Transboundary Air Pollution (LRTAP) was proposed in Geneva in 1979; the United Kingdom signed in 1982. This set an international framework for agreeing to reduction protocols. In 1985, the first protocol proposed was to reduce sulphur dioxide by $30 \%$ of the 1980 level by 1993 . The British government did not sign (Fouquet 1993).

Within the European Community, pressure was mounting for the British to accept targets. After many rounds of negotiation to introduce the Large Combustion Plant Directive, in 1988, the United Kingdom agreed to reduce its electricity generation and large industrial SO2 emissions by $20 \%$ of the 
1980 level by 1993 and by $60 \%$ of the 1980 level by 2003.This change of stance by the British coincided with plans to privatise the electricity supply industry, thus, the costs of reducing future emissions would not be incurred by the public sector (Fouquet 1993).

Indeed, a shift away from coal was achieved - from $75 \%$ of the total inputs in 1981 to $65 \%$ of the total in 1991 to $28 \%$ of the total in 2000. Between 1981 and 1991, nuclear power rose from $15 \%$ to $23 \%$ of the total and, between 1991 and 2000, natural gas increased from less than $1 \%$ of the total to $38 \%$ (Fouquet 2008). This shift has been mainly due to successive United Kingdom government's support for nuclear power until the mid 1990s and to the privatisation and liberalisation of the electricity supply industry which encouraged generators to use CCGT (Combined Cycle Gas Turbine) plants, because of lower costs of installation and because of the incumbent's desire to create overcapacity discouraging market entry (Newbery 1994).

\section{Insights for Meeting the Demand for Climate Stability}

Throughout history, citizens have been harmed by air pollution resulting from fuel combustion. The episodes discussed in this paper led to growing calls for improvements in air quality. They tended to coincide with periods of economic growth. This implies, first, that the damage increased due to greater consumption and pollution (i.e., a leftward shift in the supply curve in Figure 1), possibly with rising marginal external costs or benefits of abatement (i.e., a downward sloping demand curve). Second, peace and affluence enabled its citizens to be concerned with more than their basic economic needs (i.e., a rightward shift in the demand curve). Whether John Evelyn in the seventeenth century, the Smoke Abatement Societies in the nineteenth century or an outraged public in the mid-twentieth century, demand has put pressure on governments to introduce legislation. Despite it being a general period of low air pollution by historical (though not today's) standards, the episode with the strongest demand for improvements (see Table 2) was after the Big Smog of 1952 when the death toll in London was particularly shocking and scientists could attribute these deaths to poor air quality.

It has been proposed that the basis for climate policy lies in a domestic demand for climate policy rather than in a multilateral agreement or a supranational command (Tol 2012). There is evidence that some people in certain countries value climate stabilisation and are willing to pay to reduce greenhouse gas emissions ( $\mathrm{Li}$ et al. 2004, Cameron 2005, Berrens et al. 2006, Lee and Cameron 2008, Brouwer et al 2008, Mackerron et al 2009, Cai et al. 2010, Löschel 2010, Diedrich and Goeschl 2011). However, there is little evidence of strong support for major and costly abatement on the scale that occurred in the 1950s. 
Table 2. Summary of Historical Demand, Legislation and Substitution to Low Polluting Energy Sources

\begin{tabular}{|c|c|c|c|c|c|c|}
\hline & $\begin{array}{l}\text { Demand/ } \\
\text { Lobbying }\end{array}$ & $\begin{array}{l}\text { Governmental } \\
\text { Support }\end{array}$ & $\begin{array}{l}\text { Legislation } \\
\text { Introduced }\end{array}$ & $\begin{array}{l}\text { Legislation } \\
\text { Effective } \\
\text { Enforced } \\
\text { and } \\
\text { Sustained }\end{array}$ & $\begin{array}{l}\text { Legislation } \\
\text { on Energy }\end{array}$ & $\begin{array}{l}\text { Substitution } \\
\text { to Low } \\
\text { Polluting } \\
\text { Energy }\end{array}$ \\
\hline $1660 \mathrm{~s}$ & $\begin{array}{l}\text { Weak/ } \\
\text { Influential }\end{array}$ & $\begin{array}{l}\text { Yes } \\
\text { Not Priority }\end{array}$ & Yes? & No & No & No \\
\hline $\begin{array}{l}1840 s- \\
1890 s\end{array}$ & $\begin{array}{l}\text { Medium/ } \\
\text { Modest }\end{array}$ & $\begin{array}{l}\text { Reluctantly } \\
\text { Not Priority }\end{array}$ & Yes & No & No & No \\
\hline $\begin{array}{l}1890 \mathrm{~s}- \\
1930 \mathrm{~s}\end{array}$ & $\begin{array}{l}\text { Medium/ } \\
\text { Modest }\end{array}$ & Reluctantly & Yes & No & No & Some \\
\hline $\begin{array}{l}\text { 1950s- } \\
1960 \mathrm{~s}\end{array}$ & $\begin{array}{l}\text { Strong/ } \\
\text { Influential }\end{array}$ & $\begin{array}{l}\text { Reluctantly } \\
\text { Priority }\end{array}$ & Yes & Yes & Yes & Yes \\
\hline $\begin{array}{l}\text { 1980s- } \\
1990 \mathrm{~s}\end{array}$ & $\begin{array}{l}\text { Weak/ } \\
\text { Influential }\end{array}$ & $\begin{array}{l}\text { Reluctantly } \\
\text { Not Priority }\end{array}$ & No & No & No & Yes \\
\hline $\begin{array}{l}2000 s- \\
2010 s\end{array}$ & $\begin{array}{l}\text { Medium/ } \\
\text { Influential }\end{array}$ & Yes & Yes & $?$ & Yes & Some \\
\hline
\end{tabular}

Despite this growing literature on the relationships between the demand for climate stability and key variables, such as cultural factors, income, or potential damages, the exact causal mechanisms are not clearly understood. The evidence in this paper suggests that, while rising income does appear to be associated with greater concern, demand is likely to be greatest in periods of economic prosperity, rather than in the depths of a recession. In addition, concurring with Lee and Cameron (2008), demand grows as the perceived damages rise. Also, based on these historical experiences, the demand for climate stability will probably increase as a result of extreme and shocking events that (most will agree) can be attributed (with a high degree of confidence) to climate change.

However, even with a major demand for improvements, it is far from certain legislation will be introduced. The smoke abatement movement in the Victorian era faced a clear example of government failure because of politicians' belief that legislation would harm business and industry. This failure was driven by counter-lobbying to avoid or delay legislation, weaken its effectiveness through the wording of documents, and discourage enforcement. Clearly, pressure groups for and against climate action are seeking to sway the public and, particularly, politicians (Boyer and Laffont 1999). The strongest argument against abatement is still the fear of the economic costs of abatement, either direct or associated with an economy's competitiveness. Thus, overcoming the perceived economic damage from legislations is still the most likely way to sway politicians (Shogren 1998). 
Furthermore, just like in Victorian Britain, although legislation is being introduced, it is failing to address household behaviour, and their emissions associated with residential and transport energy consumption. In democracies, the politician's fear of angering voters weakens the effectiveness of most climate policies. It also implies that the public's demand for climate stability is especially fragile.

So, even with effective legislation introduced, for it to be sustained (i.e., enforced and not revoked by future governments), it must be of limited cost to polluters, and pro-legislation pressure groups must continue to maintain their pressures on politicians. For demand to be sustained, it will either require a series of shocking events, or a wide scale change in value systems that can support and in lifestyles that can accommodate long term political pressure. Indeed, the opposite is more likely - those that are suffering from the legislation are willing to pay for the legislation to not be enforced or to be rejected by successive governments. Also, the lags involved in environmental "markets" means that if government introduces legislation, those seeking improvements may have to wait a decade or more to assess the success of these policies.

Although not directly about energy-related air pollution, the Alkali Act of 1863 shows that environmental legislation can be effective if the victims are sufficiently influential, the polluters are clearly defined and observable group, relatively cheap solutions are available and equipment exists for monitoring pollution levels. Under such circumstances, manufacturers can be open to reducing emissions and government willing to introduce legislation. This also suggests that legislation targeted at specific groups may be more effective and sustainable than when covering a heterogeneous array of polluters.

Another lesson is how the demand for environmental improvements is being met. In a number of instances, the reaction was first containment of the problem, then dispersion of (or exporting) the problem. Although countries are exporting their carbon dioxide emissions, such as through the importing of goods, this is even less of a solution for a global pollutant. Similarly, but without a clear historical precedent, carbon sequestration, in its various guises, offers another approach to dealing with emissions without actually reducing them. This approach is, therefore, potentially attractive to many consumers as it does not affect lifestyles, work or the market for energy greatly; although, at present, the costs of carbon capture are expensive.

A further solution was and is to promote energy efficiency improvements. Markets have an incentive to seek efficiency improvements in order to provide energy services at lower prices, and have been especially successful over the last two hundred years (Fouquet 2011a). Thus, governments can aid markets to work towards further energy efficiency improvements. Unfortunately, especially in developing countries, rebound effects may eat-up some of the savings and, in the longer run, rising 
income levels are likely to lead to more demand for energy services and energy (Fouquet and Pearson 2012). So, efficiency measures cannot solve the problem on their own.

Transitions to low polluting energy sources have been and are clear solutions to specific environmental problems. Independently of governments, markets can seek the energy transition option. History tells us that a niche non-free-riding demand can exist for low carbon energy sources and technologies. This demand will be greater if the sources and technologies have desirable characteristics that fossil fuels and their related equipment do not have. One powerful driver of demand in the past, as seen in the demands for gas and electric cookers, has been social status. Thus, if low carbon sources and technologies can be seen as status-enhancing, they may achieve an important niche demand. If this niche demand develops, and producers can achieve economies of scale, then the prices can become competitive with fossil fuels. In this case, markets can drive the transition to a low carbon economy.

More probably, though, government will need to create the demand for these energy sources. Transitions often require the discovery of new solutions for many different sectors and services, the transformation of energy systems (which are complex), and the decline of energy industries and technologies that are represented by powerful pressure groups (Fouquet 2010). Thus, given the scale of the change and the time they take to unfold, governments tend to be reluctant to push for energy transitions in the first instance. Furthermore, transitions have and may create new environmental problems (such as coke and town gas, petroleum products, nuclear power or even certain renewable energy sources). Nevertheless, the experience of the Clean Air Act of 1956 shows that, with sufficient pressure and resolve, governments can initiate transitions to low polluting energy sources.

Inevitably, the direction taken to meet the demand for environmental improvement reflects a tension between political and economic forces, and not always the most socially beneficial course of action that is followed. The direction chosen to achieve climate stability will reflect the costs of abatement associated with low energy sources and technologies, efficiency improvements, carbon sequestration and geo-engineering, and the influence of the pressure groups representing the various options.

Ultimately, the broader lessons are more subtle than the standard textbook view proposing that markets fail and governments have to intervene, or even that both tend to fail. These experiences suggest that both markets and government can eventually play a role in meeting environmental concerns. First, governments tend not to prioritise environmental legislation. They only introduce effective, enforced and sustained legislation when the conditions are ideal or the pressure is unavoidable. The Alkali Act of 1863 and the Clean Air Act of 1956 show that broader legislation can be effective - but, like in the latter case, it may come one hundred years later than was probably socially optimal (Fouquet 2011b). 
Second, viewed over a century or more, markets can also adapt to environmental demands (such as the shift to suburbia at the end of the nineteenth century, the demand for gas and electric cookers in the early twentieth century, and the dash for gas). However, apart for the latter case, they tend to do so very slowly and not necessarily in a socially optimal way - after all, they seek the cheapest or most profitable solution. Thus, it would seem unwise to wait for markets on their own to solve environmental problems. It might take centuries and luck, and not be a satisfactory outcome.

Finally, crucial to the outcome of the episodes reviewed was the evolution of ideology, of government attitudes towards intervention and of the relationship between the market and the state. It would be difficult to identify trends in the forces over the next century. Nevertheless, they will evolve, such as perhaps new beliefs about our relationship with nature or the potential globalisation of markets and governments, and will play an important role in determining any transition to a low carbon economy.

\section{Conclusion}

The purpose of this paper was to understand the long run demand for energy-related environmental quality, its influence on legislation and on the substitution to low polluting energy sources. Although it did not focus exclusively on energy transitions, it sought to present some of the forces that drive a transition to low polluting energy sources.

It started by presenting a simple framework of the relationship between the demand for and supply of environmental quality, environmental legislation and energy. It started with the standard argument that the market for environmental quality fails, thus, generating a demand for environmental regulation. It outlined the steps required to supply effective, enforced and sustained environmental legislation, which can seek to influence the supply of environmental quality by a number of ways, including exporting pollution, encouraging pollution abatement or energy efficient technology, or switching to low polluting energy sources and technologies. It identified numerous factors that can lead government to fail to meet this demand. Rather than claiming to be a powerful model of behaviour, this framework simply offers one way of investigating the long run processes that lead from an environmental concern to a potential change in environmental quality.

Previously, this framework has been briefly used to discuss the rapid decline and improvements in air quality experienced during the Victorian era (Fouquet 2011b). Here, it formed the structure for presenting a series of episodes in British history where a demand for improvements in energy-related environmental quality existed. This review of historical environmental demand focussed on five episodes: the seventeenth century, the Victorian era, and the early-, mid and late-1900s. Each experience was quite distinct and offered insights about the validity of this framework, its 
weaknesses, and about details that it cannot incorporate. It was proposed that these insights were useful for understanding the long run process and barriers to meeting demands for climate stability, possibly through a transition to low carbon energy sources.

Gathering and using evidence is fraught with difficulty, especially as the processes under observation can unfold over different time periods - demand can form in days; legislation can take months to introduce; but, markets can take years, decades or even centuries to change. In addition, historical data is inevitably inconsistent and frequently inaccurate.

Furthermore, to present these episodes within the proposed framework, it may have failed to emphasise or even identify certain important determinants of the process. In particular, a combination of factors and the co-evolution of a number of institutions and organisations need to occur in parallel and underlie these changes. Indeed, there were many economic, social, political and cultural transformations that were happening simultaneously and had important bearings on the episodes discussed. Space was the limiting factor in drawing-on these important aspects of change, and should be integrated more fully in future work. A good complement to the current paper is Turnheim and Geels (2012), which analyses the decline of the coal industry and its demand through a coevolutionary lens.

Finally, there are considerable differences between the past and the future. One obvious difference is the characteristics of the demand for improvements in air pollution and for climate stability, as well as the related legislative issues and energy markets. For instance, the latter addresses a global stock pollutant, with the potential for international spillovers of ideas and technologies to address the problem.

Despite the limitations of the present paper, it is proposed that the insights discussed above are valuable. It is possible that low carbon energy sources and technologies will become cheaper than fossil fuels, in which case markets can drive the transition to low polluting energy sources. This may occur first in some countries where renewable energy resources are unusually abundant and cheap. Alternatively, it might occur in a country where consumers refuse to free-ride and demand low polluting energy. Then again, if the markets do not drive the transition, governments will need to push it, and this cannot be expected without strong and sustained demand for climate stability. Yet, while demand is a prerequisite, it is not enough. It must also be spearheaded by strong, creative and sustained pressure groups (i.e., powerful lobbying and the weakening of the counter-lobby) to introduce legislation, to enforce it and to avoid it being overturned by future governments.

At present, however, it is highly doubtful whether, in any country, there exists a stable demand for climate stability large or powerful enough to drive the long run changes necessary to achieve a transition to a low carbon economy. Thus, the author of this paper wonders whether history might not 
repeat itself, and, through a combination of markets and governments, mostly failing, but at times responding to a weak demand, climate stability will eventually be achieved, at the very least, one hundred years later than was socially optimal.

\section{References}

Allen, R.C. 2012, forthcoming. Backward into the Future: The Shift to Coal and Implications for the Next Energy Transition. Energy Policy.

Andreoni, J., Levinson, A. 2001. The simple analytics of the environmental Kuznets curve. Journal of Public Economics 80(2) 269-286.

Batoletto, S., Rubio, M.d.M., 2008. Energy Transition and CO2 Emissions in Southern Europe: Italy and Spain (1861-2000). Global Environment 2, 46-81.

Bell, M.L., Davis, D.L., Fletcher, T. 2004. A retrospective assessment of mortality from the London smog episode of 1952: the role of influenza, temperature, and pollution. Environmental Health Perspectives 112(1), p. 6-8.

Berrens, R.P., Bohara, A.K., Jenkins-Smith, H.C., Silva, C.L. and Weimer, D.L. 2006. Information and Effort in Contingent Valuation Surveys: Application to Global Climate Change using National Internet Samples', Journal of Environmental Economics and Management, 47, 331-363.

Blacconiere, W.G. and Patten, D.M. 1994. Environmental disclosures, regulatory costs, and changes in firm value. Journal of Accounting and Economics 18: 357-77.

Brimblecombe, P. 1987. The Big Smoke: A History of Air Pollution in London Since Medieval Times. Methuen. London.

Brimblecombe, P. 2006. The Clean Air Act after 50 Years. Weather 61(11) 311-4.

Brunner, R.D. and Klein, R. 1999. Harvesting experience: A reappraisal of the U.S. Climate Change Action Plan. Policy Sciences 32(2):133 161.

Bowden, S.M. 1988. The consumer durables revolution in England, 1932-1938: A regional analysis. Explorations in Economic History 25: 42-59.

Bowle, J. 1981. John Evelyn and his World. Routledge and Kegan. London.

Boyer, M. and Laffont, J.J. 1999. Toward a political theory of the emergence of environmental incentive regulation. Rand Journal of Economics 30(1): 13757. 
Brasington, D.M. and Hite, D. 2005. Demand for environmental quality: a spatial hedonic analysis. Regional Science and Urban Economics 35: 57- 82.

Breton, A. 1974. The Economic Theory of Representative Government. Aldine Publishing Co. Chicago.

Breton, A. and Wintrobe, R. 1975. The equilibrium size of a budget maximising bureau. Journal of Political Economy. 83(1): 456-69.

Brouwer, R., Brander, L. and Van Beukering, P. 2008, “A convenient truth": Air travel passengers' willingness to pay to offset their CO2 emissions, Climatic Change 90(3), 299-313.

Buchanan, J.M. 1968. The Demand and Supply of Public Goods. Rand McNally. Chicago.

Buchanan, J.M. and Vanberg, V.J. 1988. The politicization of market failure. Public Choice 57: 10113.

Burnett, J. 1986. A Social History of Housing 1815-1985. Methuen. London.

Cai, B., Cameron, T.A., and Gerdes, G. 2010. Distributional Preferences and the Incidence of Costs and Benefits in Climate Change Policy. Environmental and Resource Economics, 46, (4) 429-458.

Cameron, T.A. 2005. Individual option prices for climate change mitigation. Journal of Public Economics, 89, (2-3) 283-301.

Carson, R. 2010. The Environmental Kuznets Curve: seeking empirical regularity and theoretical structure. Review of Environmental Economics and Policy. 4(1) 3-23.

Church, R. 1986. The History of the British Coal Industry. Vol 3. 1830-1913. Clarendon Press. Oxford.

Cipolla, C.M. 1962. The Economic History of World Population. Pelican Books. London.

Clay, K., Troesken, W. 2010. Did Frederick Brodie Discover the World's First Environmental Kuznets Curve? Coal Smoke and the Rise and Fall of the London Fog, NBER Working Papers 15669. National Bureau of Economic Research.

Cole, M.A. 2004. Trade, the pollution haven hypothesis and the environmental Kuznets curve: examining the linkages. Ecological Economics 48(1) 71-81.

Dasgupta, S., Laplante, B., Wang, H., Wheeler, D. 2002. Confronting the environmental Kuznets curve. The Journal of Economic Perspectives 16(1) 147-168. 
Demographia. 2011. London Urbanized Area: Historical Estimated Population \& Density. http://www.demographia.com/db-lonuza1680.htm.

Diederich, J. and Goeschl, T.: 2011, Willingness to Pay for Individual Greenhouse Gas Emissions Reductions: Evidence from a Large Field Experiment, Discussion Paper No. 517. Department of Economics, Heidelberg University.

Dijkstra, B.R. 1998. A two stage rent seeking contest for instrument choice and revenue division, applied to environmental policy. European Journal of Political Economy 14(2): 281301.

Dingle, A.E. 1982. The Monster Nuisance of All': Landowners, Alkali Manufacturers, and Air Pollution, 1828-64. Economic History Review 35(4) 529-548.

Dorfman, R. 1977. Incidence of the benefits and costs of environmental programs. American Economic Review 67 333-340.

Doyle, Sir A.C. 2003. The Complete Sherlock Holmes: Volume II. Barnes \& Noble Classics. New York, NY.

Evelyn, J. 1661. Fumifugium; or the inconveniencie of the aer and smoak of London dissipated. Godbid. London.

Fernandez, R. and Rodrik, D. 1991. Resistance to reform: status quo bias in the presence of individual specific uncertainty. American Economic Review 81: 1146-55.

Fouquet, R. 1993. International Bargaining and the EC Large Combustion Plant Directive. Discussion Paper 70. Surrey Energy Economics Centre. Guildford, Surrey.

Fouquet, R. 2008. Heat Power and Light: Revolutions in Energy Services. Edward Elgar Publications. Cheltenham and Northampton, MA, USA.

Fouquet, R. 2010. The Slow Search for Solutions: Lessons from Historical Energy Transitions by Sector and Service. Energy Policy. 38(10) 6586-96.

Fouquet, R. 2011a. Divergences in long run trends in the prices of energy and energy services. Review of Environmental Economics and Policy 5(2) 196-218.

Fouquet, R. 2011b. Long run trends in energy-related external costs. Ecological Economics 70(12) 2380-9.

Fouquet, R., Pearson, P.J.G., 1998. A thousand years of energy use in the United Kingdom. The Energy Journal 19(4), 1-41. 
Fouquet, R., Pearson P.J.G. 2012, forthcoming. The Long Run Demand for Lighting: Elasticities and Rebound Effects in Different Phases of Economic Development. Economics of Energy and Environmental Policy 1(1).

Foxon, T.J., Köhler, J., Oughton, C., 2008. Innovation for a Low Carbon Economy: Economic, Institutional and Management Approaches. Edward Elgar Publ. Cheltenham and Northampton, MA.

Gales, B., Kander, A., Malanima, P., Rubio, M.d.M., 2007. North vs South: Energy Transition and Energy Intensity in Europe over 200 years. European Review of Economic History 11(2), 219-53.

Geels, F.W., 2002. Technological transitions as evolutionary reconfiguration processes: A multi-level perspective and a case-study. Research Policy 31(8/9), 1257-74.

GLA. 2002. 50 Years On: The Struggle for Air Quality in London since the Great Smog of December 1952. Greater London Authority. London.

Goodall, F. 1999. Burning to Serve: Selling Gas in Competitive Markets. Landmark Publishing. Ashbourne.

Grubb, M., Jamasb, T., Pollitt, M.G. 2008. Delivering a Low-Carbon Electricity System: Technologies, Economics and Policy. Cambridge: Cambridge University Press.

Grübler, A. 2004. Transitions in energy use. Encyclopedia of Energy 6: 163-77.

Grübler, A., Nakicenovic, N., Victor, D.G. 1999. Dynamics of energy technologies and global change. Energy Policy 27, 247-80.

Humphrey, W., Stanislaw, J. 1979. Economic growth and energy consumption in the UK, 1700-1975. Energy Policy 7(1) 29-42.

Jackson, A.A. 2003. The London railway suburb, 1850-1914, in: Evans, A.K.B. and Gough, J.V. (eds.) The Impact of the Railway on Society in Britain: Essays in Honour of Jack Simmons. Ashgate. Adershot.

Jackson, M.P. 1974. The Price of Coal. Croom Helm. London.

Jenner, M. 1995. The politics of London air John Evelyn's Fumifugium and the Restoration. The Historical Journal 38(3) 535-51.

Jevons, H.S. 1915. The British Coal Trade. Kegan Paul Trench Turner. London.

Jevons, W.S. 1865. The Coal Question. Macmillan. London. 
Joskow, P.L. and Schmalensee, R. 1998. The political economy of market-based environmental policy: the U.S. Acid Rain Program. Journal of Law and Economics 41: 37-83.

Kahn, M.E. 2002. Demographic change and the demand for environmental regulation. Journal of Policy Analysis and Management 21(1) 45-62.

Kahn, M.E. 2007. Environmental disasters as risk regulation catalysts? The role of Bhopal, Chernobyl, Exxon Valdez, Love Canal, and Three Mile Island in shaping U.S. environmental law. Journal of Risk and Uncertainty 35(1) 17-43.

Keohane, N.O., Revesz, R.L., Stavins, R.N. 1998. The choice of regulatory instruments in environmental policy. Harvard Environmental Law Review 22: 313-67.

Khannaa, N., Plassmann, F. 2004. The demand for environmental quality and the environmental Kuznets Curve hypothesis. Ecological Economics 51(3) 225-36.

Kolstad, C.D. 2006. Interpreting Estimated Environmental Kuznets Curves for Greenhouse Gases. The Journal of Environment and Development 15(1) 42-49.

Kristrom, B., Riera, P. 1996. Is the income elasticity of environmental improvements less than one? Environmental and Resource Economics 7(1) 45-55.

Kunnas, J., Myllyntaus, T., 2009. Postponed Leap in Carbon Dioxide Emissions: The Impact of Energy Efficiency, Fuel Choices and Industrial Structure on the Finnish Energy Economy, 1800-2005. Global Environment 3.

Lee, J. and Cameron, T.A. 2008. Popular Support for Climate Change Mitigation: Evidence from a General Population Mail Survey. Environmental and Resource Economics, 41(2) 223-248.

Li, H., Berrens, R.P., Bohara, A.K., Jenkins-Smith, H.C., Silva, C.L. and Weimer, D.L. 2004. Would developing country commitments affect US households' support for a modified Kyoto Protocol? Ecological Economics, 48: 329-343.

López, R. Mitra, S. 2000. Corruption, pollution, and the Kuznets environment curve. Journal of Environmental Economics and Management 40(2) 137-50.

Löschel, A., Sturm, B. and Vogt, C. 2010. The demand for climate protection: an empirical assessment for Germany, ZEW Discussion Papers (10-068). Centre for European Economic Research (ZEW), Mannheim.

Luckin, B. 2000. The pollution in the city. In Daunton, M.J. (ed.) The Cambridge Urban History of Britain: 1840-1950. Cambridge University Press. Cambridge. 
MacKerron, G. J., Egerton, C., Gaskell, C., Parpia, A. and Mourato, S. 2009. Willingness to pay for carbon offset certifcation and co-benefits among (high) flying young adults in the UK. Energy Policy 37(4) 1372-1381.

Madureira, N.L., 2008. When the South emulates the North: energy policies and nationalism in the twentieth century. Contemporary European History 17(1), 1-21.

McConnell, K.E. 1997. Income and the demand for environmental quality. Environment and Development Economics 2(4) 383-399.

Ministry of Power. 1961. Statistical Digest. HMSO. London.

Mosley, S. 2001. The Chimney of the World: A History of Smoke Pollution in Victorian and Edwardian Manchester. The White Horse Press. Brighton.

Mosley, S. 2010. The Environment in World History. Routledge. Abingdon.

Newbery, D.M. 1994.The impact of sulfur limits on fuel demand and electricity prices in Britain. The Energy Journal 15(3) 19-41.

Niskanen, W.A. 1971. Bureaucracy and Representative Government. Aldine-Atherton. Chicago.

Oates, W.E. and Strassmann, D.L. 1978. The Use of Effluent Fees to Regulate Public Sector Sources of Pollution: An Application of the Niskanen Model. Journal of Environmental Economics and Management. 5(3) 28391.

Pearson, P.J.G. 1994. Energy externalities and environmental quality: will development cure the ills it creates. Energy Studies Review 6(3): 199-216.

Schurr, S., Netschert, B., 1960. Energy in the American Economy, 1850 1975. John Hopkins Press. Baltimore, MD.

Shogren, J.F. 1998. A political economy in an ecological web. Environmental and Resource Economics 11(3-4): 557-70.

Scarrow, H.A. 1972. The Impact of British Domestic Air Pollution Legislation. British Journal of Political Science 2(3) 261-282.

Stevens, P.E. 1996. The economics of science.' Journal of Economic Literature 34(3): 297-306.

Thorsheim, P. 2002. The paradox of smokeless fuels: gas, coke and the environment in Britain, 18131949. Environment and History $8381-401$. 
Thorsheim, P. 2006. Inventing Pollution: Coal, Smoke, and Culture in Britain since 1800. Ohio University Press. Athens, Ohio.

Tol, R. 2012, forthcoming. Long live the Kyoto Protocol. In Fouquet, R. (ed.) Handbook on Energy and Climate Change. Edward Elgar Publications. Cheltenham and Northampton, MA, USA.

Turnheim, B., Geels, F.W. 2012, forthcoming. Industry destabilisation in socio-technical transitions: lessons from the history of the British coal industry (1913-1997). Energy Policy.

Whiteread, M. 2011. Science and the Skies: Governmentalities of the British Atmosphere. WileyBlackwell. Chichester. 


\title{
BC3 WORKING PAPER SERIES
}

\author{
Basque Centre for Climate Change (BC3), Bilbao, Spain
}

The BC3 Working Paper Series is available on the internet at the following addresses:

http://www.bc3research.org/lits_publications.html

http://ideas.repec.org/s/bcc/wpaper.html

BC3 Working Papers available:

2010-15

2010-16

2010-17

2011-01

2011-02

2011-03

2011-04

2011-05

2011-06

2011-07

2011-08

2011-09

2011-10

2011-11

Karen Pittel and Dirk Rübbelke: Local and Global Externalities, Environmental Policies and Growth

Margherita Grasso, Matteo Manera, Aline Chiabai, and Anil Markandya: The Health Effects of Climate Change: A Survey of Recent Quantitative Research

Luis Mari Abadie, Ramon Arigoni Ortiz and Ibon Galarraga: The Determinants of Energy Efficiency Investments in the U.S.

Roger Fouquet: Long Run Trends in Energy-Related External Costs

Dirk Rübbelke: International Support of Climate Change Policies in Developing Countries: Strategic, Moral and Fairness Aspects

Melanie Heugues: Endogenous Timing in Pollution Control: Stackelberg versus Cournot-Nash Equilibria

Karen Pittel and Dirk Rübbelke: International Climate Finance and its Influence on Fairness and Policy

Wan-Jung Chou, Andrea Bigano, Alistair Hunt, Stephane La Branche, Anil Markandya, Roberta Pierfederici: Households' WTP for the Reliability of Gas Supply

Roger Fouquet and Peter J.G. Pearson: The Long Run Demand for Lighting: Elasticities and Rebound Effects in Different Phases of Economic Development

Ibon Galarraga, David Heres Del Valle and Mikel González-Eguino: Price Premium for High-Efficiency Refrigerators and Calculation of Price-Elasticities for Close-Substitutes: Combining Hedonic Pricing and Demand Systems

Anil Markandya, Mikel González-Eguino, Patrick Criqui, Silvana Mima: Low Climate Stabilisation under Diverse Growth and Convergence Scenarios

Martin Altemeyer-Bartscher, Anil Markandya and Dirk Rübbelke: The Private Provision of International Impure Public Goods: the Case of Climate Policy

Aline Chiabai, Ibon Galarraga, Anil Markandya and Unai Pascual: The Equivalency Principle for Discounting the Value of Natural Assets: An Application to an Investment Project in the Basque Coast

Roger Fouquet: The Demand for Environmental Quality in Driving Transitions to Low Polluting Energy Sources 